\title{
The Mediating Effect of Organizational Trust on the Link between the Areas of Work Life and Emotional Exhaustion
}

\author{
Pinar Bayhan Karapinar ${ }^{1}$ \\ Hacettepe University
}

\author{
Selin Metin Camgoz ${ }^{2}$ \\ Hacettepe University
}

\author{
Ozge Tayfur Ekmekci ${ }^{3}$ \\ Hacettepe University
}

\begin{abstract}
The study tests an integrative model that considers the plausible effects of different areas of work life on emotional exhaustion. It also tests the mediating effect of organizational trust on this relationship. More specifically, while perceived incongruence in six areas of work life (workload, fairness, reward, community, control and value) is treated as a predictor of emotional exhaustion, organizational trust is treated as a mediating factor in understanding the underlying mechanism of emotional exhaustion in academicians. Data were collected from 201 academicians working in public universities in Turkey and were analyzed using a structural equation model. Results provided partial support for the proposed conceptual model. Specifically, organizational trust mediated the link between four areas of work life (i.e., workload, fairness, reward, and value) and emotional exhaustion. Contrary to our expectations, the mediating effect of organizational trust was found to be insignificant for community and control. Findings suggest the importance of building organizational trust by focusing on six areas of work life in order to prevent burnout in academicians.
\end{abstract}

Keywords

Workload $\bullet$ Fairness $\bullet$ Reward $\bullet$ Community $\bullet$ Control $\bullet$ Value $\bullet$ Burnout $\bullet$ Organizational trust

\footnotetext{
1 Correspondence to: Pinar Bayhan Karapinar (PhD), Department of Business Administration, Faculty of Economics and Administrative Science, Hacettepe University, Ankara 06532 Turkey. Email: pbayhan@hacettepe.edu.tr

2 Department of Business Administration, Faculty of Economics and Administrative Science, Hacettepe University, Ankara 06532 Turkey. Email: selinm@hacettepe.edu.tr

3 Department of Business Administration, Faculty of Economics and Administrative Science, Hacettepe University, Ankara 06532 Turkey. Email: otayfur@hacettepe.edu.tr

Citation: Bayhan Karapinar, P., Metin Camgoz, S., \& Tayfur Ekmekci, O. (2016). The mediating effect of organizational trust on the link between the areas of work life and emotional exhaustion. Educational Sciences: Theory \& Practice, 16, 1947-1980.
} 
Academicians have a lot of flexibility in how they spend their time, not only in terms of hours per week, but also in how they schedule teaching, administrative, research, and publishing related activities (Siegall \& Mc Donald, 2004). However, the time when academic institutions were regarded as a low-stress working environment has come to pass (Chen et al., 2014). Instead, academic faculty members working at universities are faced with overloaded work schedules (Dillion \& Tanner, 1995), challenging demands from diverse student populations (Byrne, 1999), and limited opportunities for promotion. At the same time, they are under high pressure to improve their academic and teaching performance while also being subject to increasingly demanding criteria and standards in academic publications (Tumkaya, 2006). Such harsh organizational requirements imposed on academic staff has caused growing interest in understanding faculty members' emotional reactions to adverse work conditions and stressors. Among emotional reactions, burnout merits special attention because its resulting negative consequences are on the increase at an ever accelerating rate in educational institutions. Such consequences include accelerated turnover intentions (TI), reduced quality of teaching and research, absenteeism, and detachment (e.g., Erkutlu, Chafra, \& Bumin, 2011; Murat, 2003).

Although a vast amount of studies conducted in educational institutions have examined burnout syndrome (Maslach, 1993), much of the work has focused on helping individuals by suggesting various coping strategies (Dworkin, 2001). Schwab and Iwanicki (1982, p. 62) state that "many organizations have launched programs to combat burnout without understanding what it is, why it exists, or even whom it is effecting." So, scholars start to argue that this traditional individualistic approach is inefficient in providing the realistic picture of burnout and commented that "the causal elements of burnout are to be seen within the structure of the school or the structure of the educational system" (Dworkin, 2001, p. 70). Thus, it is of worth to adopt a wider perspective while examining academician burnout. In this case, the researchers attempted to observe it through an organizational lens.

Maslach and Leiter (1997) described six areas of work life (AW) in an organizational context coming together and encompassing major organizational antecedents of burnout: These areas are workload, fairness, control, community, reward, and values. Accordingly, burnout arises from mismatches between people and their work settings manifesting in six areas (Leiter \& Maslach, 1999). It has been reported that burnout levels for academicians are now comparable with those of other education and service professionals (Watts \& Robertson, 2011). As indicated previously, teaching staff in higher education institutions currently face increasing demands and experience high pressure to equip themselves with the necessary skills to respond to the demands of dynamic environment (Chen et al., 2014). When academicians do not experience a sense of wellbeing at work, they experience high levels of stress, become more 
dissatisfied with their job, and suffer from greater emotional exhaustion (Trent, 1997). Therefore, this study takes as its base assumption that work environment can fully account for what had previously been considered an individual syndrome of burnout (Lasalvia et al., 2009) and then explores the role of perceived contextual factors on exhaustion.

Although some research has focused on the linkage between workplace factors in AW and burnout, by what means these factors influence burnout has not been adequately investigated. For this reason, this paper focuses on organizational trust, which simply reflect employees' willingness to be vulnerable to their organizations' actions (Paliszkiewicz, 2011), as a transmitting mechanism. Accordingly, this degree of vulnerability increases in situations where parties are interdependent to each other. In a society dominated by collectivistic culture like Turkey, trust and faith in one's organization and superiors are important values not only for the integration of individuals and employee relationships, but also for the structure of organizations (Farh \& Earley, 1997). Moreover, rested on the socially embedded and subjective nature of most interactions in educational institutions (Cummings \& Bromiley, 1996), trust is thought to be affected by workplace factors. Therefore, we contend that the perceived incongruence manifesting in six areas of work life are plausible antecedents and that organizational trust is a mediating factor in understanding the underlying mechanism causing emotional exhaustion in academicians. More specifically, we treat organizational trust as an important job resource that aids employees in reducing their job demands. We argue that when academicians perceive their organizations as having failed to fulfill their promises in six areas of work life, the relationships of trust existing between academicians and their organization breaks and manifests itself in increased levels of emotional exhaustion.

Different from prior studies, this paper distinguishes itself (a) by focusing on the mediating role of organizational trust on the hitherto inadequately explored link between various areas of work life and emotional exhaustion and (b) by simultaneously testing the effects of workload, fairness, reward, community, control, value congruence, and organizational trust on emotional exhaustion as major components of burnout.

\section{Literature Review}

\section{Emotional Exhaustion}

Job burnout is regarded as a psychosocial syndrome that involves a prolonged response to stressors in the workplace (Maslach, 2003, p. 189). Accordingly, the burnout process consists of three dimensions, namely emotional exhaustion, 
depersonalization /cynicism, and reduced personal accomplishment (Maslach \& Jackson, 1986). Although conceptualized as a three-dimensional construct, some researchers argue that emotional exhaustion is the core dimension of burnout (Green, Walkey, \& Taylor, 1991; Shirom, 2003) and that individuals mostly experience greater emotional exhaustion when burned out (Byrne, 1991). Emotional exhaustion, being the outcome variable affected by the adverse work conditions addressed in the current study, refers to feelings of being depleted and exhausted by the emotional demands of one's work (Maslach, Schaufeli, \& Leiter, 2001). Therefore, we have decided to focus on emotional exhaustion not only because this dimension represents the core of burnout, but also because it is affected mostly by organizational stressors (Byrne 1991; Lackritz, 2004). Burnout is regarded as a serious problem in educational staff, including academicians in both Turkish (Ardıç \& Polatc1, 2008; Budak \& Sürgevil, 2005; Özkanal \& Arıkan, 2010; Toker, 2011) and Western literature (Van Horn et al., 1999, p. 372). In this regard, academicians working under stressful conditions with constantly changing educational policies, gradually feel powerless and unable to deal with stress, leading them to become inadequate in performing their tasks and eventually to emotional exhaustion (Tumkaya, 2006).

\section{Areas of Worklife and Emotional Exhaustion}

This study assesses adverse work conditions in six areas of work life (Leiter \& Maslach, 2004; Maslach \& Leiter, 1997). Workload refers to individuals' expended energy and consumed time at work. In other words, it is the perception of job demands relative to one's limits. Fairness, found in the literature on equity and social justice, is the perception of fair decisions and respectful treatment at work. It refers to whether and to what extent an organization applies consistent and equitable rules and whether it deals with every one of its employees with respect and justice. Control is regarded as one of the most important organizational factors. Lack of control is believed to occur when employees have insufficient authority over work or are unable to shape their work environment in a way consistent with their values. Community reflects the overall quality of workplace social interactions. More specifically, it is related to how people solve conflicts, support each other, and work as a team. Reward refers to what extent monetary, social, and intrinsic rewards are consistent with expectations. Value is related to the congruence between an organization's goals and expectations and those of its employees. It emphasizes the motivational connection between an individual and his workplace that goes beyond the utilitarian exchange of time for money. These work factors were found to affect, albeit at varying degrees, the dimensions of burnout (Leiter \& Maslach, 2004; Maslach \& Leiter, 1997). 
In the present study, we base our propositions mainly upon the job demand resources (JD-R) model of burnout (Bakker \& Demerouti, 2007; Bakker, Demerouti, De Boer, \& Schaufeli, 2003) to explain how academicians' perceptions regarding areas of work life affect their trust in organizations and thereby affect their emotional exhaustion. The job demands-resources model is an occupational stress model that suggests strain to be a response to an imbalance between demands on the individual and the resources at his disposal to deal with those demands (Bakker \& Demerouti, 2007). This theory basically argues that every job has its own specific working characteristics that can be categorized as job demands and job resources. Irrespective of the type of job performed, job strain is most likely to occur when job demands are high and when job resources are limited (Bakker et al., 2003). More specifically, high job demands exhaust employees' physical and mental resources, leading them to experience a complete depletion of energy (Brom, Buruck, Horvath, Richter, \& Leiter, 2015). In contrast, high amounts of resources fosters employee engagement (Brom et al., 2015) by providing employees with coping strategies to deal with work stressors. In addition to the JD-R model, some of our propositions are based upon the effort-balance imbalance theory (Siegrist, 1996), which emphasizes the role of effort-outcome imbalance in energy depletion. In congruence with the effortimbalance theory, we also borrow from the norm of reciprocity, which stresses the importance of frustration on burnout resulting from unmet expectations (Kim, 2011). In the following paragraphs, theoretical evidence suggesting the link between the dimensions of AW and emotional exhaustion are summarized.

Workload and emotional exhaustion. The effects that workload has on emotional exhaustion is mostly explained by means of the JD-R (Bakker \& Demerouti, 2007) and Demand Control Model (DCM) of job stress (Karasek \& Theorell, 1990). Accordingly, perceived workload is one of the key factors discussed in these theories' job demand component and it has been operationalized mainly in terms of time pressure and role conflict (Karasek, 1979). Likewise, DCM expresses job stress as being the result of high workplace demands joined with a perception of low control (Karasek, 1979). Leiter and Maslach (2004) argue that workload becomes a problem specifically when the work being done is excessively complex, intense, and time demanding. That is, emotional exhaustion is most likely to occur when job demands exceed human limits (Leiter \& Maslach, 2004). Supporting this notion is Lee and Ashford's (1996) meta-analysis study, in which they found high workload to be associated with high emotional exhaustion. The workload dimension is especially important in terms of burnout development in academicians. Academicians feel stress and exhaustion when they perceive that work demands interfere with their personal lives and interrupt the recovery cycles necessary to sustain active involvement in their profession (Leiter \& Maslach, 2004). More specifically, academic staff members working at universities are now faced with overloaded work schedules, under greater 
pressure to produce more research and publication facilities, expected to increase the quality of their teaching, and involved in intensive interactions with a higher number of students (Watts \& Robertson, 2011). Therefore, high workload could exhaust academicians' energy reserves (Schaufeli \& Bakker, 2004), which might lead them to perform what their job demands of them in an increasingly ineffective manner and to increasingly higher levels stress. Consistent with this, the literature on AW shows that employees with a manageable workload (i.e. employees experiencing congruence between expected and actual workload) were found to feel lower levels of emotional exhaustion (Gascón et al., 2013; Leiter \& Maslach, 2004). Thus we presume the following hypotheses:

Hypothesis 1.1. A manageable workload will translate into lower levels of emotional exhaustion.

Fairness and emotional exhaustion. In the context of organizational predictors of emotional exhaustion, perceived inequity has emerged as a powerful source. Individuals evaluate not only how fair decisions and procedures are, but also the quality of the relationship between the decision-maker and those affected by the decision. Perceptions of inequity by individuals is argued to result in negative affective and emotional reactions, escalated levels of stress, and burnout. As argued in the norm of reciprocity, unmet expectations regarding the decision making process and personal interactions lead individuals to feel increasingly higher levels of frustration and psychological distress (Tepper, 2001), which in turn result in exhaustion. In addition to the norm of reciprocity, the JD-R model could explain the association between perceived injustice and negative feelings, particularly emotional exhaustion. Fairness could act as the resource component in the JD-R model by providing employees with a sense of being valued by the organization. This sense of fair treatment then alleviates the detrimental effects of high job demands. Consistent with these premises, the literature also provides empirical evidence indicating that those employees perceiving organizational injustice are more likely to experience burnout and emotional exhaustion among service employees (Van Yperen, Buunk, \& Schaufeli, 1992) and teachers (Van Horn et al., 1999). Likewise, the existence of fairness is found to be a valuable factor for coping with stress (Kroon, van de Voorde, \& van Veldhoven, 2009) and preventing burnout (Noblet \& Rodwell, 2009). Deriving from the aforementioned relationship, it might be assumed that academicians' perceptions of fairness regarding workplace outcomes or processes might have effects on their stress levels. Such that when academicians evaluate their work practices as being fair, their tendency to feel emotionally exhausted will become less prevalent. Thus:

Hypothesis 1.2. Higher levels of perceived fairness will translate into lower levels of emotional exhaustion. 
Community and emotional exhaustion. Being a member of a group satisfies individuals' desire for affiliation and relatedness, which in turn reduces the impact of job stressors (Buunk et al., 1993) and demands, as suggested by the JD-R model. By acting as a job resource, emotional exchange and instrumental assistance provided by other colleagues and supervisors not only reduces exhaustion (Cordes \& Dougherty, 1993; Maslach et al., 1996), but also acts as a buffer against the impact of adverse work conditions (Tayfur \& Arslan, 2013; Truchot \& Deregard, 2001). According to Angerer (2003), some professions, including teaching, can lead to employees to feel isolated even though these professions require their employees to be in constant human contact. In fact, Brock and Grady (2000) found the physical isolation of teaching to be a factor contributing to increased burnout. Recently, Edwards, Van Laar, and Easton (2009) reported that poor working relationship with colleagues and the lack of university support as two important sources of job stress for academicians. It is therefore reasonable to expect a perceived lack of community to increase emotional exhaustion.

Hypothesis 1.3. Higher levels of perceived sense of community will translate into lower levels of emotional exhaustion.

Control and emotional exhaustion. Though academicians can control whether they enter the profession and, to a certain extent, their area of expertise, they cannot control the size of the demands (i.e. increasing number of students and changing promotion criteria) placed upon them (Clark, 1986). Moreover, multiple authorities with conflicting demands may interfere with academicians' abilities to set their own career goals and to determine their career paths. Leiter and Maslach (2004) state that this kind of role conflict not only reduces one's sense of control, but also promotes burnout. In line with both Angerer's (2003) arguments and Job-Demand-Resource Control Theory (Karasek \& Theorell 1990), lack of control is found to be strongly and positively related to emotional exhaustion (Cherniss, 1980; Lee \& Ashforth, 1993; Leiter, 1992). In a recent study, Edwards et al. (2009) explained the increasing level of job stress among British academicians with their perceived lack of job control. Thus, we expect sense of control to negatively predict emotional exhaustion.

Hypothesis 1.4. Higher levels of perceived sense of control will translate into lower levels of emotional exhaustion.

Reward and emotional exhaustion. Academicians show effort to achieve valued outcomes, such as student progress, fair promotion prospects, and recognition. The relationship between reward and organizational outcomes, including burnout, can be explained by the Effort- Reward Imbalance theory (Siegrist, 1996). This theory suggests that the discrepancy between efforts and outcomes usually results in energy depletion because of the inconsistency between individuals' expectations and gains. 
When employees perceive to be neglected by the organization's reward system, they have a higher tendency to feel out of sync with its values (Brom, Buruck, Horvath, Richter, \& Leiter, 2015). Supporting this theory's assertion, previous studies report that insufficient rewards and lack of recognition decreases employees' resilience to burnout (Chappell \& Novak, 1992; Maslanka, 1996). More specifically, it is reported that individuals who have experienced an imbalance in efforts and rewards are more likely to feel emotionally exhausted than those who have not (Bakker, Kilmeri, Sigrist, \& Schaufeli, 2000; Frenkel, Li, \& Restubog, 2012). Therefore, we propose that academicians experiencing a discrepancy between their efforts and outcomes are more likely feel emotionally exhausted.

Hypothesis 1.5. Higher levels of reward attainment will translate into lower levels of emotional exhaustion.

Value and emotional exhaustion. Since they reflect the ideals and motivation that originally attract employees to the job (Leiter \& Maslach, 2004), values are regarded as one of the core aspects of work life. The impact of value incongruence can also be explained by the Person-environment fit theory which has gained support in organizational psychology (French et al., 1974 as cited in Siegall \& McDonald, 2004). The theory argues that the congruence between organizational values, personal beliefs, and preferences are key aspects in an individual's wellbeing (Posner, 1992). When employees experience a gap between their values and organizational values, they find themselves making a trade-off between the work they want to do and the work they have to do. Such value incongruence could adversely affect employee's wellbeing by accelerating tension, strain, and burnout. Furthermore, as JD-R model argues, having compatible values with the organization could act as a resource component by giving employees a sense of contributing meaningful personal goals (Leiter \& Maslach, 2004), which in turn provides energy to face job demands. Dealing with value conflicts, on the other hand, could deplete the energy that employees would otherwise exert to deal with job demands, thereby causing feelings of emotional exhaustion. Moreover, value conflicts could decrease employees' involvement in their work by creating de-motivating working conditions in which employees are discouraged from pursuing what they truly value. Decline in involvement and demotivating conditions could eventually increase the prevalence of burnout.

Empirical studies support the aforementioned linkage between value congruence and employee wellbeing. In these studies, value congruence is found to be negatively related to burnout in different professions (Siegall \& McDonald, 2004). For instance, based on a sample of Norwegian physicians, Langballe, Innstrand, Aasland, and Falkum (2010) report that the congruency between employee and workplace values is key in preventing exhaustion. Leiter, Frank, and Matheson (2009) state that value congruence 
predict exhaustion in other human service professions. With the data obtained from 135 university professors, Siegall and McDonald (2004) report that person-organization value incongruence is strongly associated with burnout and causes teachers to spend less time on teaching, service/administrative tasks, and professional development activities. Similarly, Leiter and Shaughnessy (2006) demonstrate that academicians feeling value mismatch are not only more likely to feel that their university is insincere about its stated values, but also to experience more workplace conflicts. Thus:

Hypothesis 1.6. Higher levels of value congruence will translate into lower levels of emotional exhaustion.

\section{Areas of Work Life and Organizational Trust}

Trust is defined as "the willingness of a party to be vulnerable to the actions of another party based on the expectation that the other party will perform a particular action important to the trustor irrespective of the ability to monitor or control that other party" (Mayer, Davis, \& Schoorman, 1995, p.712). In general, it is the belief that someone is reliable, good, and honest (Webster, 2014), provides the basis for social order, facilitates stability, cooperation, and cohesion (Tschannen- Moran, 2001) and increases student achievement (Tschannen-Moran \& Hoy, 2001) in academic institutions. Although not investigated directly, different scholars (e.g., Acosta, Salanova, \& Llorens, 2012) suggest that organizational practices and a perceived match between expectations and practices play a significant role in increasing organizational trust. Areas of work life as a valid and widely known measure of congruence between organizational practices and employees' expectations could be used as a predictor of organizational trust. In this sense, theoretical evidence for the link between AW dimensions and trust are summarized below:

Workload and organizational trust. Although no direct research has associated academic workload and organizational trust, it can be argued that academicians are likely to incur stress in the event that their workload and responsibilities increase without being allotted additional time or resources. As workload is one of the most important components of the job demand model, being overwhelmed with exceeding demands in one's work life decreases an individuals' capacity to meet the requirements of his job. Fatigue resulting from excessive demands events then puts the individual into vulnerable positions that reduce his propensity to trust others (Bayhan Karapinar, 2015). Under such circumstances, the employee may continue to reevaluate the costs and benefits of the organization, possibly exhibiting fluctuations in trust perceptions. We thus argue that the congruence between perceived and actual workload is important in academicians' organizational trust perceptions. 
Hypothesis 2.1. The existence of manageable workload will translate into higher levels of organizational trust.

Fairness and organizational trust. De Coninck (2010) indicates that both fairness and trust emphasize the importance of consistency and that moreover, they are important facets of social exchange. Accordingly, fair treatment enhances social exchange relationships, thereby increasing levels of trust (De Coninck, 2010). As such, it may be argued that one of the driving forces of organizational trust is employees' perception of fairness. In line with this argument, the literature confirms the existence of a positive relationship between employees' perceptions of fairness and their trust in the organization (Aryee, Budhwar, \& Chen, 2004, DeConinck, 2010, Hubbell \& Chory-Assad, 2005). Meta-analyses also reveal that there exists a significant relationship between fairness perceptions and organizational trust (Colquitt, Conlon, Wesson, Porter, \& Ng, 2001; Dirks \& Ferrin, 2002). Similarly, Brockner and Siegel (1996) report that the presence of structured and interactionally fair procedures increases trust, whereas the lack of perceived structural and procedural fairness elicit lower levels of organizational trust. Thus we propose:

Hypothesis 2.2. Higher levels of perceived fairness will translate into higher levels of organizational trust.

Community and organizational trust. In regard to community, educational research has focused primarily on collaboration and social support among teachers, colleagues, principals, and administrators. Academicians often use collaboration to share their research and teaching ideas and to help each other solve problems. Tschannen- Moran (2004) suggests that collaboration among members enhances trust within any organization, specifically within schools. Moreover, it is argued that receiving social support in an organization plays an important role in the development of trust. That is, feelings of trust develop toward the organization in the event that support is appreciated and mutually reciprocated between two parties, such as between colleagues and/or administrators. In their meta-analysis, Dirks and Ferrin (2002) report a high correlation between perceived organizational support and organizational trust. Similarly, Dulac, Coyle-Sharpiro, Henderson, and Wayne (2008) found perceived organizational support as a direct, significant predictor of organizational trust. Further, Eisenberger, Fasolo, and Davis-LaMastro (1990, p. 57) conclude that "perceived support would create trust that the organization will fulfill exchange obligations of noticing and rewarding employee efforts made on its behalf." In Turkey, both Aykan (2007) and Tasdan and Yalcın (2010) investigated the relationship between teachers' organizational social support and trust perceptions in both pre and primary school levels. Their findings indicate positive correlations between primary school teachers' perceived social support and organizational 
trust. Therefore, we expect the concept sense of community to positively predict organizational trust.

Hypothesis 2.3. Higher levels of perceived sense of community will translate into higher levels of organizational trust.

Control and organizational trust. Control problems occur when employees do not have enough discretion over their work or when they are unable to shape their environment according to their values (Leiter \& Maslach, 2004). Control may enhance the alignment of various parties' interests by compensating for negative behavioral expectations (e.g. the fear of opportunistic behavior). In this regard, control is considered to be an important element in building trust (Vosselman, \& Van der Meer-Kooistra, 2009). Specifically, having a sense of control over work outcomes and relationships, reduces the need to control the organization's actions. Therefore, control, as a component of the JD-R model, may serve to generate positive behavior expectations that serve as the foundation for building organizational trust. Based on this reasoning, we hypothesize that employees' tendency to trust their organizations will increase as they feel that they have control over what they do in the organization:

Hypothesis 2.4. Higher levels of perceived sense of control will translate into higher levels of organizational trust.

Reward and organizational trust. A balance between the effort employees put in and the rewards they receive for doing so is likely to have a relationship with organizational trust since the organization controls the rewards valued by its employees. Adams (1965) suggests that inequitable allocations elicit distress, with anger resulting from underpayment inequity, on the one hand, and guilt resulting from overpayment inequity, on the other. Such negative emotions might undermine the development of reciprocal investments (Colquitt et al., 2012). Accordingly, when employees perceive that the organization rewards them in a manner consistent with their expectations, their perceptions will become more favorable, Feeling that the organization values their contributions, their trust in their organizations will continue to increase (Sousa-Lima, Michel, \& Caetano, 2013). The literature demonstrates that trust in one's organization is strongly related to whether employees' expected rewards are actually allocated to them (Aryee, Budhwar, \& Chen, 2002; Hopkins \& Weathington, 2006). Recently, Sousa-Lima, Michel, and Caetano (2013) have demonstrated that feelings of trust in one's organization can be improved by distributing rewards in a fair manner. In line with prior research, the following hypothesis is proposed:

Hypothesis 2.5. Higher levels of reward attainment will translate into higher levels of organizational trust. 
Value congruence and organizational trust. Value congruence results in employees believing that they will not be harmed by their organization (Enz, 1988), this being one of the core dimensions of trust. Reflecting the amount of overlap between an individual's personal values and the values that one perceives to exist in his organization, value congruence works to build trust by creating a sense of commonality shared between two parties (Cazier, Shao, \& Louis, 2007). In other words, sharing common values leads one to perceive that his organization follows a set of principles considered to be acceptable by its employees and allows its employees to predict organizational decisions and events (Cazier et al., 2007; Mayer et al., 1995). Thus, value congruence is seen to breed organizational trust by creating a positive organizational climate (Hughes, Avey, \& Norman, 2008). Relevant research on value congruence has also indicated that shared values promote trust to develop in relationships (Christiansen, Villanova, \& Mikulay, 1997; Lau, Liu, \& Fu, 2007). More recently, Edwards and Cable (2009) have also reported that value congruence is related to trust. Collectively, these arguments lead the following hypothesis.

Hypothesis 2.6. Higher levels of value congruence will translate into higher levels of organizational trust.

\section{Organizational Trust and Emotional Exhaustion}

The relationship between organizational trust and emotional exhaustion can be explained through the JD-R Model (Bakker \& Demerouti, 2007). Just as organizational trust might be effective in assisting employees to achieve their work goals, reduce job demands, and experience personal growth, it also contributes to removal of the monitoring cost of the employees.

There is relatively little written on the direct association between organizational trust and burnout within the literature. Dirk and Ferrin (2002) propose that when employees believe their management staff to be untrustworthy, they are likely to feel psychologically distressed, which in turn influences their own well-being. In Wong and Cummings's (2009) study, trust in management was found to be negatively correlated with job burnout both in clinical (e.g., nurses and health care professionals) and nonclinical (e.g., administrative) groups. Stress also can be a precipitating factor in educational staffs' burnout. For instance, Ceyanes (2005) report that teachers having low trust in their principal are more likely to experience high levels of burnout. Likewise, Likewise In Turkey, Çağlar's study (2011) exploring the correlations between the sub-dimensions of organizational confidence and the dimensions of burnout found there to be a negative correlation between the level of organizational confidence and teachers' emotional burnout. Driving from that association, Çağlar 
(2011) reports that those factors effective in increasing organizational confidence in schools are also influential in reducing staff burnout levels.

H3. Higher levels of organizational trust will translate into lower levels of emotional exhaustion in academicians.

\section{Mediating Effect of Organizational Trust}

Consistent with the above-mentioned research in the literature, trust tends to mediate between the six areas of work life (workload, fairness, reward, community, control, and value) and with emotional exhaustion. There are specific reasons as to why trust plays such a meditating role. First, trust has the ability to transform the one's expectation of the other parties' goodwill and supportive intentions (Mayer et al., 1995), which in turn acts as a kind of transforming mechanism from work areas to psychological outcomes $(\mathrm{Li}, 2008)$. This means that trust may be regarded as a potential motivating or demotivating factor that triggers psychological constructive (i.e., well-being) or deconstructive (i.e., exhaustion) outcomes in employees.

Second, we evoke the notion of reciprocity and of Rousseau's (1989) psychological contract breach as the theoretical framework for the effects of organizational antecedents on employees' organizational trust. Psychological contract breach means that the employee's expectation of reciprocal obligations between himself and the organization has been broken. Whether a breach has occurred or not is usually subjective in nature, meaning that the perceived breach depends on employee's evaluation as to just what the organization's obligations are in the first place. This breach is an essential element on the relationship between the employee and the organization because it affects the employee's attitudes and job outcomes. Accordingly, when employees experience a breach of their psychological contract, they perceive inconsistencies between the employers' words and actions, who might then exhibit any number of behavioral and/or attitudinal reactions toward their organizations (Kickul \& Lester, 2001). As time passes, such employees become increasingly less confident that their contributions will be reciprocated by their organizations in the future. This suspicion may work to erode employees' trust in their organizations. When trust no longer exists, employees' energy risk being depleted, resulting in an increase in emotional exhaustion. When academicians perceive that their university consistently fails to fulfill promised obligations in the six areas of work life (workload, fairness, reward, community, control and value), they then begin to lose trust in their university, which might then manifest in the form of increased levels of emotional depletion.

The relevant theories and literature findings reviewed cited while proposing the previous hypotheses (H1.1-H1.6 and $\mathrm{H} 2.1-\mathrm{H} 2.6)$ show that mediation conditions 
apply to the current study: (a) The areas of work life dimensions are related to emotional exhaustion (b) the work life dimensions relate to organizational trust, and (c) organizational trust is related to emotional exhaustion. Thus, it is plausible to expect that areas of work life act as distal workplace stressors believed to affect organizational trust, serving in turn as proximal predictors of academicians' emotional exhaustion. The conceptual model is consistent with the mediation model such that:

$\mathrm{H}$ 4. Organizational trust acts as a mediator between areas of work life and emotional exhaustion

The relationships implied by our hypotheses are illustrated in Figure 1.

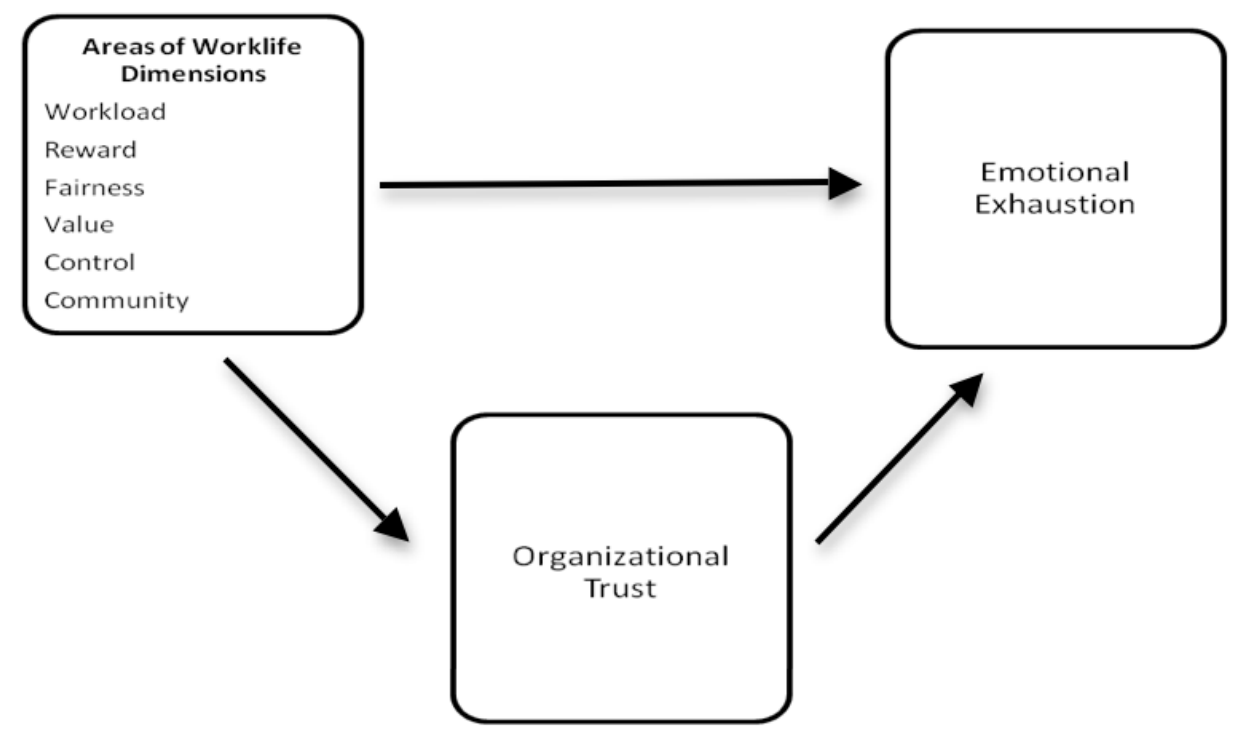

Figure 1. Proposed model.

\section{Method}

\section{Sampling}

The study sample consisted of academicians working at two public universities located in Ankara, the capital city of Turkey. These two universities employ a total of 7,728 academic faculty members, including research assistants, instructors, assistant professors, associate professors, and professors from all faculties. Given this population, a power analysis was conducted using an alpha of .05 , and it was found that 258 subjects were required to achieve a power of .80. Considering the possibility of non-responses, we distributed a total of 350 questionnaires through convenience 
sampling and obtained 201 useable questionnaires (57.4\% response rate). Among the 201 respondents, $44 \%(\mathrm{n}=90)$ worked in one university and the remaining $56 \%$ $(\mathrm{n}=111)$ worked in the other. The majority of the participants were women between the ages of 25 and 35 followed by women between 18 and 25. The sample was composed of $70 \%$ research assistants, $17 \%$ instructors and assistant professors, and the remaining $13 \%$ associate professors and professors.

\section{Data Collection Tools}

In order to ensure the conceptual equivalence of the items, three scales (exhaustion, trust, and AW) were translated into Turkish using a collaborative translation technique. The researchers and one graduate student translated the scales independently after which another graduate student fluent in both languages examined these two translations and the original scale to determine which translation was better based on clarity as well as lexical and conceptual equivalence. All scales were used with the permission of the copyright holders.

Emotional exhaustion was measured using the five items of the Maslach Burnout Scale: General Survey (Schaufeli, Leiter, Maslach, \& Jackson, 1996). These items assess feelings of being emotionally overextended, drained, and exhausted by one's work (e.g., I feel emotionally drained from my work). Responses are measured on a 7 -point scale format ranging from $1=$ never to $7=$ always. Higher mean scores correspond to higher degrees of experienced emotional exhaustion. Like previous studies, the reliability of the exhaustion subscale was found to be high $(\alpha=.90)$.

Organizational Trust Inventory (OTI). Trust was measured using the 12item short version of the OTI using a response scale whose scores ranged from (1) strongly disagree to (5) strongly agree (Cummings \& Bromiley, 1996). Although it has affective, cognitive, and behavioral dimensions, it has been conceptualized as a single dimension in many studies. An example item is "We think that the organization takes advantage of people who are vulnerable." Higher scores indicate higher degrees of trust. The reliability coefficient was .92 .

Areas of Work Life Scale (AWS). AWS assesses six areas of work life domains, including workload (5 items), reward (4 items), fairness (6 items), community (5 items), control (4 items), and value (4 items) (Leiter \& Maslach, 2006). The subscales include positively worded items of congruence and negatively worded items of incongruence. Respondents indicate their agreement with these statements on a 5-point Likert type scale. Higher scores indicate higher degrees of perceived alignment (fit) between the workplace and the academicians' expectations. Since positively worded items reflect congruence regarding six areas of work life, trust 
is expected to have a positive relation with these dimensions, while exhaustion is expected to have a negative relation with them. The reliability coefficients of the AWS dimensions range from .60 to .85 .

Having been originally developed in other languages and then translated into Turkish, the factorial equivalence of the scales needed to be established. Confirmatory factor analyses (CFA) were conducted to ensure the existence of this equivalence and to compare the dimensions obtained with the original questionnaire. Specifically, we conducted two separate factor analyses, one for AW and the other for the scales measuring mediating and outcome variables. In this first measurement model, 29 items of AW were assigned to 6 dimensions (i.e., workload, control, community, reward, fairness, and value). In the second measurement model, the remaining items were assigned to exhaustion and trust dimensions. In all measurement models, the variance of constructs was set at 1.00 and all correlations among the factors/constructs were freed. Since there are no severe violations of normality of distributions, a maximum likelihood approximation was used as an estimation method. In the CFA and later in path analyses, we assessed the relationships between items and dimensions by examining the statistical significance of t-values $(p<.05)$ and model fit (Chi-Square, Chi Square / degrees of freedom, Comparative Fit Index (CFI), and Root Mean Square Error of Approximation (RMSEA)) with the criteria suggested by MacCallum, Browne, and Sugawara (1996).

The initial examination of the first CFA suggested the similarity of the factor structure of with the original version. However, two items that were supposed to measure workload and value dimensions were not found to be significantly related to these dimensions. Following the suggestions of Bryne (2001), these items were removed from the model. The revised model produced a fit $\left(\chi_{(280)}^{2}=698.80, p<.001 ; \chi^{2} / \mathrm{df}=2.46\right.$; $\mathrm{CFI}=.81 ; \mathrm{RMSEA}=.08)$ much better than the original model $\left(\chi_{(335)}^{2}=783.31, p<.001\right.$; $\left.\chi^{2} / \mathrm{df}=2.34 ; \mathrm{CFI}=.79 ; \mathrm{RMSEA}=.08\right)$. Although all item coefficients were significant on the assigned factor, the modification indices indicated significant error correlations. However, as Kline (2011) states, freeing error correlations may increase the risk of arbitrarily improving the model fit. We freed a limited number of error correlations (8 out of 55) and these error correlations were limited to correlations of the same factor. After this modification, the model produced the 4 largest item's error correlations, produced a relatively better fit $\left(\chi_{(280)}^{2}=589.9, p<.001 ; \chi^{2} / \mathrm{df}=2.14 ; \mathrm{CFI}=.86\right.$; $\left.\mathrm{RMSEA}=.07\right)$. Based on these results, we decided to use 26 items of AWS to calculate composite scores of workload (4 items), value (3 items), community (5 items), reward (4 items), control (4 items), and fairness (6 items).

In the second measurement model, all item coefficients were found to be significant on the assigned factor. However, when we examined the modification 
indices, we detected significant error correlations that adversely affected goodness of model. Following the same procedure detailed above, we freed the 7 largest error correlations, which produced a much better fit $\left(\chi^{2}{ }_{(118)}=250.60, p<.001 ; \chi^{2} / \mathrm{df}=2.26\right.$; $\mathrm{CFI}=.93 ; \mathrm{RMSEA}=.07)$ than the initial model $\left(\chi_{(118)}^{2}=399.70, p<.001 ; \chi^{2} / \mathrm{df}=3.39\right.$; $\mathrm{CFI}=.86$; RMSEA $=.11$ ). Considering the goodness of fit and t-values of the items, we decided to use 17 items to calculate the composite scores of exhaustion (using 5 items) and organizational trust (using 12 items).

\section{Procedure}

The current study utilized a cross sectional research design as research procedure. The questionnaire did not contain any details that could be used to identify the academicians. Data were kept in such a manner that only the researchers had access to the questionnaire in order to ensure total confidentially. Informed consent was given to every participant prior to inclusion. The authorization of the University Ethical Board was taken for the study. The self-report survey included measures of organizational trust, emotional exhaustion, and areas of work life. Responses to all of the following multi-item scales were averaged to form composite variables.

\section{Analyses}

Prior to analysis on the areas of work life, organizational trust and exhaustion scores were examined using various statistical programs to ensure accurate data entry and normality while at the same time searching for missing values. Missing values were replaced with the mean values of their respective variables. Univariate and multi variate normality were assessed using Kolmogorov -Smirnov and Mardina coefficient tests, respectively (Kline, 2011). No severe violations of normality were detected. After data screening, following the suggestions of Anderson and Gerbing (1988), we first conducted a confirmatory factor analysis (CFA) to examine the factorial structures of the scales, after which we conducted a path analysis to test the hypotheses. We preferred to perform a path analysis over the traditional 4-step mediation analysis detailed by Baron and Kenny (1986). Using the path analysis enabled us to analyze the mediating effects $\mathrm{c}$ for more than one predictor variables. More specifically, we were able to analyze the mediating effects of all AW and examine their complex relations. In addition to this, the path analysis may be considered superior based on the argument put forward by MacKinnon, Lockwood, Hoffman, West, and Sheets (2002) stating that Baron and Kenny's (1986) approach has very low power. The path analysis and CFA were conducted using the AMOS 17 program (Arbuckle, 2008). 
After ensuring factorial equivalence, we calculated the composite scores for each variable (i.e., workload, control, community, reward, fairness, values, emotional exhaustion, and trust) by averaging the responses given to scale items. We then tested a structural model depicting the proposed mediating model. We checked both the significance of the hypothesized relations and the model's goodness of fit by examining the t-values and several fit indices, respectively.

Following Shrout and Bolger's (2002) suggestions, we also examined our model using the bootstrap resampling method to establish confidence intervals for testing the statistical significance of the mediation. We believe that using the bootstrapping approach would afford greater statistical power than the normal theory approach used in the structural model (MacKinnon, Lockwood, \& Williams, 2004), thereby enabling us to check the results of path analysis. Using bootstrapping, we were able to report confidence intervals (both corrected and uncorrected) and the significance values of indirect effects.

\section{Results}

Before proceeding to path analysis, the reliability estimates and correlation coefficients were examined. As seen from the table, all constructs except workload were found to be quite reliable. Although falling below the .70 criterion suggested by Nunnally (1978, p. 245), the workload subscale could be considered acceptable considering the small number of items within the scale. Correlation coefficients, on the other hand, suggested the existence of moderate-to-strong relations between AW dimensions. The correlations among AW dimensions, trust, and exhaustion were consistent with expectations (Leiter \& Maslach, 2004): Exhaustion was negatively correlated with the six areas of work life and organization trust.

Table 1

Descriptive Statistics of Variables of Interest

\begin{tabular}{|c|c|c|c|c|c|c|c|c|c|c|c|}
\hline & $\mathrm{M}$ & $\mathrm{SD}$ & $\alpha$ & 1 & 2 & 3 & 4 & 5 & 6 & 7 & 8 \\
\hline 1.Workload & 2.78 & .79 & .60 & -- & & & & & & & \\
\hline 2. Value & 3.07 & .84 & .75 & $.21 *$ & -- & & & & & & \\
\hline 3.Fairness & 2.91 & .87 & .85 & $.28 *$ & $.68 *$ & -- & & & & & \\
\hline 4.Reward & 3.23 & .80 & .79 & $.26^{*}$ & $.55^{*}$ & $.62 *$ & -- & & & & \\
\hline 5.Control & 3.08 & .80 & .70 & $.27 *$ & $.43^{*}$ & $.54 *$ & $.46^{*}$ & -- & & & \\
\hline 6.Community & 3.48 & .70 & .71 & .10 & $.52 *$ & $.58^{*}$ & $.52 *$ & $.33 *$ & -- & & \\
\hline 7. Trust & 4.36 & 1.24 & .92 & $.33 *$ & $.62 *$ & $.72 *$ & $.60 *$ & $.43^{*}$ & $.45^{*}$ & -- & \\
\hline 8. Exhaustion & 3.67 & 1.38 & .90 & $-.41 *$ & $-.23^{*}$ & $-.32 *$ & $-.35^{*}$ & $-.22 *$ & $-.27 *$ & $-.41 *$ & - \\
\hline
\end{tabular}

Note. M: Mean of variables, SD: standard deviation, $\alpha$ : Cronbach Alpha. 
Following Preacher and Kelley's (2011) suggestion, we first tested the model by removing the mediating variable (i.e., organizational trust) from the proposed model. In doing so, we tested the significance of direct paths from the AW dimensions to exhaustion, which constitutes the initial step of any mediation testing. As seen in Table 2, all of the direct paths were found to be significant. After this, we tested the proposed model, which assumes the existence of both direct and indirect effects of AW dimensions on exhaustion. Our initial analysis of the model suggested the existence of a saturated model $(\chi 2(0)=0.0, p=.00$; CFI $=1.00$; RMSEA $=.34)$. However, some of the hypothesized paths were subsequently found to be insignificant. Except the path from workload to exhaustion, none of the direct paths from the AW dimensions to exhaustion were found to be significant, thereby rendering hypotheses $1 \mathrm{~b}, 1 \mathrm{c}, 1 \mathrm{~d}, 1 \mathrm{e}$, and $1 \mathrm{f}$ unsupported. Although this finding seems contradictory with the results of the initial model test, it is understandable given the fact that the proposed model incorporates the relationship among AW dimensions, unlike the initial model. Moreover, paths from two dimensions of AW, namely control and community to organizational trust, were found to be insignificant ( $\beta=-.13 ; p>.05$ for community; $\beta=.01 ; p>.05$ for control). As seen in table 2 , the remaining AW dimensions were found to be significantly related with trust (supporting hypotheses 2.1., 2.2., 2.5 and 2.6), which in turn negatively predicted emotional exhaustion (supporting Hypothesis 3). The existence of a direct path between workload and exhaustion suggested partial mediation. Fairness, reward, and value were found to affect emotional exhaustion only through organizational trust, indicating the existence of full mediation. Except for control and communication, the mediating effects of organizational trust on the relationship between AW dimensions and exhaustion were demonstrated, rendering hypothesis 4 supported.

As Preacher and Kelley (2011) noted, showing the significance of direct paths from an independent variable to a mediator, and from a mediator to an outcome variable is not enough to claim the existence of significant mediation effect. Following this corollary, we conducted additional analyses. Firstly, we removed the path from trust to exhaustion and then assessed the models' fit with and without this path. As expected, the model including a mediating path was significantly better than the one without a mediating path (i.e., path from trust to exhaustion was removed) $\left(\chi^{2}(1)\right.$ $=17.98 ; p<.05)$. This suggested the existence of significant mediation. Secondly, path coefficients were examined. As seen in Table 2, the path coefficients from AW dimensions to exhaustion were substantially reduced when the path from trust to exhaustion was taken into account. Lastly, we conducted a bootstrapping analysis in which we computed both unstandardized and standardized, indirect effects together with their confidence intervals. Specifically, unstandardized and standardized estimates were computed for each of the 1,000 bootstrapped samples, revealing a $95 \%$ confidence interval as a result of determining the indirect effects at the 2.5 th 
and 97.5th percentiles. As seen in Table 2, the confidence intervals calculated for the standardized indirect effects did not include 0 , indicating the existence of significant mediations.

\begin{tabular}{|c|c|c|c|c|c|c|}
\hline \multicolumn{7}{|l|}{ Table 2} \\
\hline Model & $\mathrm{b}$ & $\mathrm{SE}$ & $\beta$ & $p$ & CI (lower) & CI (upper) \\
\hline \multicolumn{7}{|l|}{ Model without mediator } \\
\hline Workload $\rightarrow$ exhaustion (c) & -.71 & .11 & -.41 & $<.001$ & -.94 & -.49 \\
\hline Reward $\rightarrow$ exhaustion (c) & -.60 & .11 & -.35 & $<.001$ & -.82 & -.37 \\
\hline Fairness $\rightarrow$ exhaustion (c) & -.50 & .10 & -.32 & $<.001$ & -.71 & -.29 \\
\hline Value $\rightarrow$ exhaustion (c) & -.38 & .11 & -.23 & $<.001$ & -.61 & -.16 \\
\hline Control $\rightarrow$ exhaustion (c) & -.38 & .12 & -.22 & $<.001$ & -.62 & -.15 \\
\hline Community $\rightarrow$ exhaustion (c) & -.60 & .12 & -.35 & $<.001$ & -.79 & -.26 \\
\hline \multicolumn{7}{|l|}{ Model with Mediator } \\
\hline Workload $\rightarrow$ Trust (a) & .18 & .08 & .12 & $<.05$ & .05 & .33 \\
\hline Reward $\rightarrow$ Trust (a) & .32 & .10 & .21 & $<.001$ & .11 & .53 \\
\hline Fairness $\rightarrow$ Trust (a) & .65 & .10 & .46 & $<.001$ & .44 & .88 \\
\hline Value $\rightarrow$ Trust (a) & .27 & .09 & .18 & $<.05$ & .06 & .48 \\
\hline Control $\rightarrow$ Trust (a) & -.02 & .09 & -.01 & .81 & -.26 & .16 \\
\hline Community $\rightarrow$ Trust (a) & -.05 & .10 & -.03 & .66 & -.25 & .16 \\
\hline Trust $\rightarrow$ Exhaustion (b) & -.45 & .10 & -.40 & $<.001$ & -.55 & -.26 \\
\hline Workload $\rightarrow$ Exhaustion $\left(\mathrm{c}^{\mathrm{I}}\right)$ & -.52 & .11 & -.30 & $<.001$ & -.73 & -.30 \\
\hline Reward $\rightarrow$ Exhaustion $\left(\mathrm{c}^{\mathrm{l}}\right)$ & -.16 & .14 & -.09 & .28 & -.48 & .18 \\
\hline Fairness $\rightarrow$ Exhaustion $\left(\mathrm{c}^{\mathrm{I}}\right)$ & .15 & .17 & .09 & .37 & -.17 & .49 \\
\hline Value $\rightarrow$ Exhaustion $\left(\mathrm{c}^{\mathrm{I}}\right)$ & .20 & .14 & .12 & .15 & -.09 & .46 \\
\hline Control $\rightarrow$ Exhaustion $\left(\mathrm{c}^{\mathrm{I}}\right)$ & .02 & .13 & .01 & .86 & -.22 & .26 \\
\hline Community $\rightarrow$ Exhaustion $\left(\mathrm{c}^{\mathrm{I}}\right)$ & -.26 & .15 & -.13 & .08 & -.55 & .07 \\
\hline Indirect effect of workload & -.08 & & -.05 & & -.18 & -.02 \\
\hline Indirect effect of reward & -.14 & & -.08 & & -.30 & -.05 \\
\hline Indirect effect of fairness & -.29 & & -.19 & & -.50 & -.14 \\
\hline Indirect effect of value & -.12 & & -.08 & & -.25 & -.03 \\
\hline Indirect effect of control & .009 & & .005 & & -.07 & .13 \\
\hline Indirect effect of community & .02 & & .01 & & -.07 & .13 \\
\hline
\end{tabular}

Note. b: Unstandardized regression estimate, SE: Standard error of unstandardized estimate, $\beta$ : standardized regression, CI (lower): confidence interval lower bound, CI (higher): confidence interval higher bound, c: direct paths from AW dimensions to exhaustion; a: direct paths from AW dimensions to trust; $\mathrm{c}^{1}$ : direct paths from AW dimensions to exhaustion when trust is included in the model.

As previously indicated, before, some paths in the proposed model were found to be insignificant. We decided to remove the insignificant paths in order to achieve more parsimonious results. Removing insignificant paths from the original model produced a much better fit to data $(\chi 2(7)=6.72, p>.001 ; \chi 2 / \mathrm{df}=.96$; GFI $=.99$; RMSEA $=.001)$. The standardized and unstandardized estimates for hypothesized paths are summarized in Figure 2. 


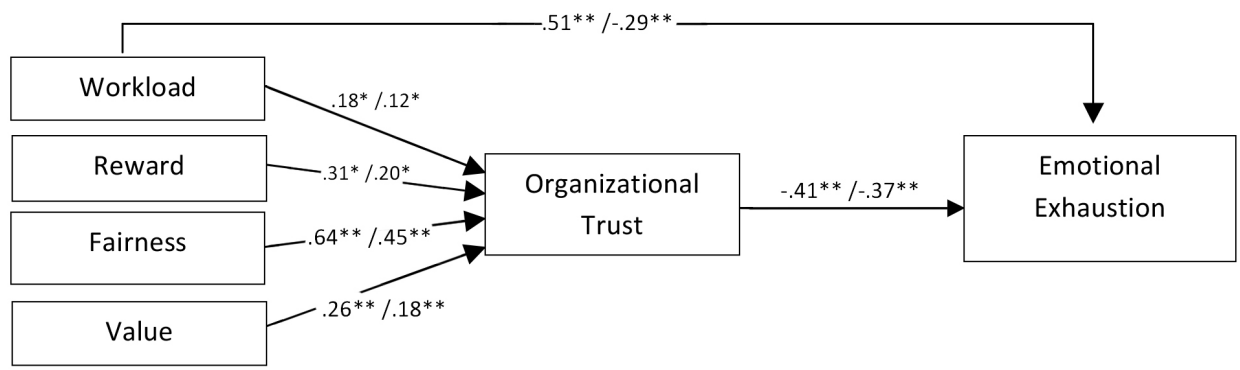

Figure 2. Results of the Path analysis.

Note. Paths from community and control to trust and exhaustion were removed from the proposed model. The numbers written before (/) represent the unstandardized estimates; numbers written after (/) represent the standardized estimates. ${ }^{*}: p<.05$; $* *: p<.01$.

\section{Discussion}

The present study has aimed to examine a model explaining academicians' emotional exhaustion by taking into account the effects of different areas of work life and organizational trust. Overall, the study's findings provide partial support for the proposed conceptual model. Our final model revealed that organizational trust plays a critical mediating role in transmitting the effects of workload, fairness, reward, and value to emotional exhaustion. This means that academicians who perceive value, rewards, workload, and fairness to be congruent were more likely to trust their organizations, which in turn reduces the prevalence of emotional exhaustion. Contrary to our expectations, the effects of control and community on organizational trust were found to be nonsignificant, rendering relevant mediation hypotheses unsupported. Moreover, workload seems to be one of the most important work stressors, given the fact that it has both direct and indirect effects on emotional exhaustion.

Another noteworthy finding is the existence of a high level of emotional exhaustion among academicians. As indicated above, we collected data mostly from research assistants, instructors and assistant professors at the beginning stages of their academic careers. High levels of exhaustion felt by young academicians, in fact, are not surprising given the results of previous studies (e.g., Tumkaya, 2006; Watts \& Robertson, 2001). Younger academicians struggle not only to obtain academic rank, but also to fulfill more administrative responsibilities, which could inadvertently result in emotional exhaustion. Moreover, being at the beginning of their careers, younger academics tend to have higher expectations that could lead to burnout if not fulfilled. 


\section{Discussion for the Main Effects of Areas of Worklife and Organizational Trust}

Despite scant research examining the relation between AW and organizational trust, the current study finds positive effects of workload, fairness, reward, and value on organizational trust. More specifically, academicians' perceived congruence between expectations and organizational practices regarding workload, fairness, reward, and value plays an important role in the development of organizational trust. These findings are consistent with the assertions of Acosta et al. (2012). Fair reward allocation and treatment combined with manageable workload was found to strengthen the social exchange relationship between employees and their organization, which in turn increases organizational trust levels (DeConinck, 2010). Similarly, when the preferences and goals of academicians overlap with those of their educational institutions, employees are more likely to believe that they will not be harmed by their organization (Enz, 1988). This feeling seems to increase mutual reciprocity and thus is effective in developing organizational trust. This finding on the effect of value congruence is in line with previous literature indicating a positive association between value congruence and organizational trust (Christiansen et al., 1997; Edwards \& Cable, 2009; Lau et al., 2007).

Despite the existence of significant correlations among community, trust, and exhaustion, the effects of both community and control were found to be insignificant. The insignificant relationships obtained for control and community dimensions seem to contradict the results of previous studies conducted by Vosselman and Van der Meer-Kooistra (2009). One might argue that the presence of multiple factors having significant correlations with trust and exhaustion could have attenuated the effects of community and control. The presence of a moderate-to-strong correlation between these two AW dimensions (i.e., community and control) and other dimensions of AW (i.e., fairness, value, and reward) also seem to reverse the signs of the estimated regression coefficients from the expected direction represented in the bivariate correlations. When this statistical problem was further analyzed using separate regression analyses, it was found that community and control significantly predicted organizational trust, suggesting the existence of spurious relations among variables. Another explanation could be related to model specification. To date, many studies have tested models proposing linear relationships in which the relationship of control with burnout is mediated through other AW dimensions. In these studies, it is assumed that the more control academicians exert at work, the more they can shape work demands to manageable levels. In this study, rather than using "control" as a factor shaping other dimensions, we tested a model that treated all AW dimensions as equally important. Therefore, it is possible that such a model specification may have rendered control's effect insignificant. 
Considering the direct effects of AW dimensions on emotional exhaustion, only the direct of workload was found to be significant, meaning that compared to other AW dimensions, workload seems to be a prominent antecedent of exhaustion affecting emotional exhaustion both directly and indirectly (Maslach, 2003; Tayfur \& Arslan, 2013). In this regard, academicians with high workloads tend not only to regard their relations with students and administration inequitably, but also feel unappreciated. This lack of appreciation and reciprocity might lead to higher levels of exhaustion. Alternatively, the effects of workload on emotional exhaustion can be explained by the JD-R model. When perceived workload is high, time allocated at work diminishes time that could otherwise be spent with one's family, and it is this time pressure that seems to deplete the people's capacity to meet job demands. In such an already stressful situation, one's family, and thoughts of not allotting sufficient time to one's family, could then become an area that adds to academicians' emotional exhaustion.

Regarding the relationship between trust and emotional exhaustion, the findings of the current study are congruent with those of previous studies (e.g. Timms, Graham, \& Caltabiano, 2006; Wong \& Cummings, 2009). The existing negative relationship between trust and emotional exhaustion suggests that academicians are more likely to feel emotionally drained when they perceive their university us untrustworthy. This finding is reasonable considering the assertion of Tschannen-Moran (2014) who argues that when trust is broken between administrative staff members and academicians, such consequences of burnout as suspicion and psychological withdrawal are likely to be observed, thereby accelerating the emotional exhaustion.

\section{Discussion for the Mediating Effect of Organizational Trust}

The current study revealed that organizational trust played a critical mediating role in transmitting the effects of workload, fairness, reward, and value to emotional exhaustion. That is, academicians who feel there to be congruence between these four AW dimensions are more likely to trust their organizations, which in turn reduces the prevalence of emotional exhaustion. It is argued that when employees perceive their organization as having failed to fulfill its promised obligations, they perceive an inconsistency between employers' words and actions (Robinson, 1996). Because of this inconsistency, an employee begins to lose confidence that the contributions he made will not be reciprocated by his employer in the future. This suspicion may then erode trust (Cummings \& Bromiley, 1996) and lead to increased stress. Being a measure of perceived congruence between academicians' expectations and workplace factors, AW could explain how organizational trust is shaped. We believe that perceived incongruence between fairness, reward, workload, and values may create a lack of inconsistency and reciprocity, which in turn erode trust toward one's university and increase the prevalence of emotional exhaustion among academicians. 
More specifically, as previously argued, perceptions of fairness are regarded as the organizational antecedents in reciprocal relationships (Masterson et al., 2000). According to Turkish cultural values, employees expect their superiors to take responsibility for others, and becoming very isolated if the employees cannot fulfill their expectations (Ertürk, 2007). In this regard, emotional exhaustion may arise as a result of diminished levels of organizational trust stemming from employees' perceptions of unfairness and of imbalance between effort and rewards. On the other hand, the literature has provided evidence that values affect employees' trust in their organizations (Moorman, Deshpande, \& Zaltman, 1993), meaning that employees experiencing high value incongruence are more likely not only to perceive their organizations as unsupportive, but to lose trust in their organizations and eventually feel exhausted. As workload is one of the most important components of the job demand model, fatigue resulting from excessive demands places individuals into vulnerable positions that reduce their propensity to trust (Bayhan Karapinar, 2015). Under such circumstances, employees whose levels of trust fluctuate begin to feel psychologically distressed, a finding congruent with those of Dirk and Ferrin (2002).

The mediation hypotheses were not supported for either the dimension of community or of control. As previously discussed, the relationship between AW dimensions may have caused the effects of control and community on both exhaustion and trust to be rendered insignificant. In addition, Leiter and Maslach (2004) noted that control might serve as the starting point in mediation models by influencing the extent to which employees can attain harmony in other areas, especially in the areas of workload, reward, fairness, and community. In this sense, control could shape employees' ability to influence other people and processes that determine the work life quality. Therefore rather than affecting organizational outcomes together with other AW dimensions, control may act as an antecedent of other AW dimensions. In future studies, placing control as the antecedents of reward, fairness, workload, and community could provide new insights about how AW dimensions shape organizational trust and exhaustion.

\section{Practical Implications}

The findings of the present study are expected to contribute to practice and policy making. Managerial and administrative staffs in universities face greater difficulties in recognizing excellent performance (reward), the internal processes for promotion (fairness), or the level of social conflicts within the workplace (community). Since mismatches between employees' expectations and those of their organization might have detrimental long-term effects on both employees and organizations, the Areas of Work Life Scale could be used to identify and to specify whether and where work 
related problems occur (Brom, Buruck, Horváth, Richter, \& Leiter, 2015). More clearly, this study reveals that AW could be used in university settings as a diagnostic tool. In doing so, universities will have a chance not only to identify developing problems early on before they become more serious and pervasive, but also to generate sound, timely, preventive solutions (Maslach \& Leiter, 2008).

Furthermore, the results of this study provide insight into how to implement programs effective in eliminating factors triggering emotional exhaustion. Improving the workplace atmosphere within educational institutions could be one of the more significant aims of employee burnout prevention implementations. The potential benefits of such programmers may, in turn, have a favorable impact on student outcomes, including an impact on academic performance and on establishing a positive learning environment. Therefore, university administration should be aware of burnout in their academicians and its organizational antecedents. The most important indication was that an individual's perceptions and experiences related to exhaustion are transmitted to exhaustion by affecting one's trust felt to his organization. Since experiencing incongruence in work-related factors is an indicator of feeling less organizational trust, preventive measures should be taken to ensure that employees' expectations are in-line with organizational practices. University administrations can formulate intervention programs that provide realistic information about work-related stressors and then demonstrate coping methods. For instance, through the use of computer programs and by designing the internal process at universities, administrators can reduce red tape and excessive paper work. Such interventions could remove the burden of engaging non-work related activities, thereby reducing workload, which in turn will both directly and indirectly affect the prevalence of emotional exhaustion. However, rather than devising intervention programs whose sole target is workload, universities might focus on other types of individual- work environment mismatch and develop more comprehensive interventions. As Lasalvia et al. (2009) point out, individuals are able to tolerate greater workload if they value their work and/or feel rewarded for their efforts. Therefore, creating an organizational culture based on integrity, openness, transparency, and concern for academicians could mitigate the effects of workload and other job demands by enhancing a sense of fairness and trust. In other terms, organizations should be alert to invest in key practices, such as organizational communication and development, in order to promote organizational trust. Investment in these practices might be interpreted by academic staff as a sign that the university is concerned about its employees, consequently leading one's trust in his organization to be enhanced (Acosta et al., 2013). 


\section{Limitations}

The limitations of this study should be acknowledged while interpreting its findings and while setting a direction for future research. The first limitation is related to method used to collect data. Since burnout is a unique response to workplace factors, it is argued that it is best measured with data obtained from employees experiencing these factors. However, the use of a methodology relying solely on self-reporting to obtain information is questionable because academicians' ability to analyze and indicate their own behavior may be tainted by a number of unforeseen factors, such as mood. In addition, relying on self-reporting may cause a problem in common method variance, a problem which could provide another explanation for the observed relationships. Although several remedies, including Harman's Test, were employed to rule out this problem, future studies could make use of other sources, such as supervisory reports, to gather information.

The second limitation is related to sampling. Results are based on a convenience sample of young academicians, namely research assistants, instructors, and assistant professors. Possible differences emanating from different problems faced by young academicians might have confounded the results. A larger randomly selected sample could increase findings' generalizability. Furthermore, future studies could test the hypotheses by using latent variable modeling rather than two-step modeling, as was used in this study. Such an approach could eliminate measurement and residual errors and thereby provide different results.

Despite the limitations listed above, this study has addressed the shortcomings in the literature by demonstrating the impact of workplace factors on emotional exhaustion through its effects on organizational trust. To the knowledge of the authors, previous studies have yet to investigate this mediation. Yet, we believe that several individual or situational factors not taken into consideration in this study may affect the feelings and interpretations of academicians. Future studies should take into account the role of other individual and situational variables, such as negative affectivity, coping ability, resilience, and university type (public or private), to explain emotional exhaustion and trust. By utilizing these moderating variables, it could be possible to attain more comprehensive model. 


\section{References}

Acosta, H., Salanova, M., \& Llorens, S. (2013). Building organizational trust: A study in small and medium-sized enterprises. In J. Neves \& S. P. Gonçalves (Eds.), Occupational health psychology: From burnout to well-being (pp. 357-378). Rosemead, CA: Scientific \& Academic Publishing. http://dx.doi.org/10.1080/21711976.2015.1016751

Adams, J. S. (1965). Inequity in social exchange. Advances in Experimental Social Psychology, 2, 267-299. http://dx.doi.org/10.1016/S0065-2601(08)60108-2

Anderson, J. C., \& Gerbing, D. W. (1988). Structural equation modeling in practice: A review and recommended two-step approach. Psychological Bulletin, 103(3), 411-423. http:// dx.doi.org/10.1037/0033-2909.103.3.411

Angerer, J. M. (2003). Job burnout. Journal of Employment Counseling, 40(3), 98-107. http:// dx.doi.org/10.1002/j.2161-1920.2003.tb00860.x

Arbuckle, J. L. (2008). Amos 17.0 User's Guide. Amos Development Corporation.

Ardıç, K., \& Polatçı, S. (2008). Tükenmişlik sendromu akademisyenler üzerinde bir uygulama (GOÜ Örneği) [A study on academicians about burnout syndrome (GOU example)]. İktisadi ve İdari Bilimler Fakültesi Dergisi, 10(2), 1-28.

Aryee, S., Chen, Z. X., \& Budhwar, P. S. (2004). Exchange fairness and employee performance: An examination of the relationship between organizational politics and procedural justice. Organizational Behavior and Human Decision Processes, 94(1), 1-14. http://dx.doi. org/10.1016/j.obhdp.2004.03.002

Aryee, S., Budhwar, P. S., \& Chen, Z. X. (2002). Trust as a mediator of the relationship between organizational justice and work outcomes: Test of a social exchange model. Journal of Organizational Behavior, 23(3), 267-285. http://dx.doi:10.1002/job.138

Aykan, E. (2007, May). Algllanan örgütsel destek ile örgütsel güven ve tükenme davranışı arasındaki ilişkilerin belirlenmesine yönelik bir araştırma [A study to determine the relationship among perceived organizational support, organizational trust and burnout behavior]. Paper presented at the XV. Ulusal Yönetim ve Organizasyon Kongresi, Sakarya University, Faculty of Economics and Administrative Sciences, Sakarya, Turkey.

Baron, R. M., \& Kenny, D. A. (1986). The moderator-mediator variable distinction in social psychological research: Conceptual, strategic, and statistical considerations. Journal of Personality and Social Psychology, 51(6), 1173. http://psycnet.apa.org/doi/10.1037/00223514.51.6.1173

Bakker, A. B., \& Demerouti, E. (2007). The job demands-resources model: State of the art. Journal of Managerial Psychology, 22(3), 309-328. http://dx.doi. org/10.1108/02683940710733115

Bakker, A. B., Demerouti, E., De Boer, E., \& Schaufeli, W. B. (2003). Job demands and job resources as predictors of absence duration and frequency. Journal of Vocational Behavior, 62(2), 341-356. http://dx.doi.org/10.1016/S0001-8791(02)00030-1

Bakker, A. B., Kilmer, C. H., Siegrist, J., \& Schaufeli, W. B. (2000). Effort-reward imbalance and burnout among nurses. Journal of Advanced Nursing, 31, 884-891. http://dx.doi. org/10.1046/j.1365-2648.2000.01361.x

Bayhan Karapinar, P. (2015). Okul yöneticisine güven: Bağlanma stilleri ile ilişkisi [Developing trust in principal: Its relationship with attachment styles]. Hacettepe Üniversitesi Ĕ̈itim Fakültesi Dergisi, 30(3), 73-86. 
Bowers, L., Nijman, H., Simpson, A., \& Jones, J. (2011). The relationship between leadership, teamworking, structure, burnout and attitude to patients on acute psychiatric wards. Social Psychiatry and Psychiatric Epidemiology, 46(2), 143-148. http://dx.doi:10.1007/s00127010-0180-8

Brock, B. L., \& Grady, M. L. (2000). Rekindling the flame: Principals combating teacher burnout. Thousand Oaks, CA: Corwin Press.

Brockner, J., \& Siegel, P. (1996). Understanding the interaction between procedural and distributive justice: The role of trust. In R. M. Kramer \& T. R. Tyler (Eds.), Trust in organizations: Frontiers of theory and research (pp. 390-413). Thousand Oaks, CA: Sage.

Brom, S. S., Buruck, G., Horváth, I., Richter, P., \& Leiter, M. (2015). Areas of worklife as predictors of occupational health: A validation study in two German samples. Burnout Research, 2, 60-70. http://dx.doi.org/10.1016/j.burn.2015.05.001

Budak, G., \& Sürgevil, O. (2005). Tükenmişlik ve tükenmişliği etkileyen örgütsel faktörlerin analizine ilişkin akademik personel üzerinde bir uygulama [A study on academic personnel about analyzing burnout and the organizational factors influencing burnout]. Dokuz Eylül Üniversitesi IIIBF Dergisi, 20(2), 95-108.

Buunk, B. P., Doosje, B. J., Jans, L. G. J. M., \& Hopstaken. L. E. M. (1993). Perceived reciprocity, social support and stress at work: The role of exchange and communal orientation. Journal of Personality and Social Psychology, 65, 801-811. http://dx.doi. org/10.1037/0022-3514.65.4.801

Byrne, B. M. (1991). Burnout: Investigating the impact of background variables for elementary, intermediate, secondary, and university educators. Teaching and Teacher Education, 7(2), 197-209. http://dx.doi.org/10.1016/0742-051X(91)90027-M

Byrne, B. M. (1999). The nomological network of teacher burnout: A literature review and empirically validated model. In R. Vandenberghe \& A. M. Huberman (Eds.), Understanding and preventing teacher burnout (pp. 15-38). Cambridge, UK: Cambridge University Press. http://dx.doi.org/10.1017/CBO9780511527784.003

Bryne, B. M. (2001). Structural equation modeling with AMOS: Basic concepts, applications, and programming. Mahwah, NJ: Lawrence Erlbaum Associates.

Cazier, J. A., Shao, B. B., \& Louis, R. D. S. (2007). Sharing information and building trust through value congruence. Information Systems Frontiers, 9(5), 515-529. http://dx.doi. org/10.1007/s10796-007-9051-6

Ceyanes, J. W., \& Slater, R. O. (2005, April). Does teacher trust in the principal influence teacher burnout? Paper presented at The American Educational Research Association (AREA) Annual Meeting, Montreal, Canada.

Chappell, N. L., \& Novak, M. (1992). The role of support in alleviating stress among nursing assistants. The Gerontologist, 32(3), 351-359. http://dx.doi.org/10.1093/geront/32.3.351

Chen, W. S., Haniff, J., Siau, C. S., Seet, W., Loh, S. F., \& Abd, M. H. (2014). Burnout in Academics: An Empirical Study in Private Universities in Malaysia. The International Journal of Social Sciences and Humanities Invention, 1(2), 62-72.

Cherniss, C. (1980). Staff burnout: Job stress in the human services. Beverly Hills, CA: Sage.

Christiansen, N., Villanova, P., \& Mikulay, S. (1997). Political influence compatibility: Fitting the person to the climate. Journal of Organizational Behavior, 18, 709-773. http://dx.doi. org/10.1002/(SICI)1099-1379(199711)18:6\%3C709::AID-JOB811\%3E3.0.CO;2-4 
Clark, S. M. (1986). The academic profession and career: Perspectives and problems. Teaching Sociology, 14(1), 24-34. http://dx.doi.org/10.2307/1318296

Colquitt, J. A., Conlon, D. E., Wesson, M. J., Porter, C. O., \& Yee Ng, K. (2001). Justice at the millennium: A meta-analytic review of 25 years of organizational justice research. Journal of applied psychology, 86(3), 425-445. http://dx.doi.org/10.1037/0021-9010.86.3.425

Colquitt, J. A., LePine, J. A., Piccolo, R. F., Zapata, C. P., \& Rich, B. L. (2012). Explaining the justice-performance relationship: Trust as exchange deepener or trust as uncertainty reducer? Journal of Applied Psychology, 97(1), 1-15. http://dx.doi.org/10.1037/a0025208

Cordes, C. L., \& Dougherty, T. W. (1993). A review and an integration of research on job burnout. Academy of Management Review, 18(4), 621-656. http://dx.doi.org/10.5465/ AMR.1993.9402210153

Cummings, L. L., \& Bromiley, P. (1996). The organizational trust inventory (OTI): Development and validation. In R. Kramer \& T. Tyler (Eds.), Trust in organizations: Frontiers of theory and research (pp. 302-330). : Thousand Oaks, CA: Sage.

Çağlar, Ç. (2011). An examination of teacher's occupational burnout levels in terms of organizational confidence and some other variables. Educational Sciences: Theory \& Practice, 11, 1841-1847.

DeConinck, J. B. (2010). The effect of organizational justice, perceived organizational support, and perceived supervisor support on marketing employees' level of trust. Journal of Business Research, 63, 1349-1355. http://dx.doi.org/10.1016/j.jbusres.2010.01.003

Dillon, J. F., \& Tanner, G. R. (1995). Dimensions of career burnout among educators. Journalism and Mass Communication Educator, 50(2), 4-13. http://dx.doi. org/10.1177/107769589505000201

Dirks, K. T., \& Ferrin, D. L. (2002). Trust in leadership: Meta-analytic findings and implications for research and practice. Journal of Applied Psychology, 87(4), 611-628. http://dx.doi. org/10.1037/0021-9010.87.4.611

Dulac, T., Coyle-Sharpiro, J. A. M, Henderson, D. J., \& Wayne, S. J. (2008). Not all responses to breach are the same: The interconnection of social exchange and psychological contract processes in organizations. Academy of Management Journal, 51(6), 1079-98. http:// dx.doi.org/10.5465/AMJ.2008.35732596

Dworkin, A. G. (2001). Perspectives on teacher burnout and school reform. International Education Journal, 2(2), 69-78. Retrieved from http://www.flinders.edu.au/ehl/education/ iej

Edwards, J. A., Van Laar, D., Easton, S., \& Kinman, G. (2009). The work-related quality of life scale for higher education employees. Quality in Higher Education, 15(3), 207-219. http://dx.doi.org/10.1080/13538320903343057

Edwards, J. R., \& Cable, D. M. (2009). The value of congruence. Journal of Applied Psychology, 94, 654-677. http://dx.doi.org/10.1037/a0014891

Eisenberger, R., Fasolo, P., \& Davis-LaMastro, V. (1990). Perceived organizational support and employee diligence, commitment, and innovation. Journal of Applied Psychology, 75(1), 51-59. http://dx.doi.org/10.1037/0021-9010.75.1.51

Enz, C. A. (1988). The role of value congruity in intraorganizational power. Administrative Science Quarterly, 33(2), 284-304. http://dx.doi.org/10.1080/13538320903343057 
Erkutlu, H., Chafra, J., \& Bumin, B. (2011). Organizational culture's role in the relationship between power bases and job stress. Hacettepe University Journal of Education, 40, 198-209.

Ertürk, A. (2007). Increasing organizational citizenship behaviors of Turkish academicians: Mediating role of trust in supervisor on the relationship between organizational justice and citizenship behaviors. Journal of Managerial Psychology, 22(3), 257-270. http://dx.doi. org/10.1108/02683940710733089

Farh, J. L., Earley, P. C., \& Lin, S. C. (1997). Impetus for action: A cultural analysis of justice and organizational citizenship behavior in Chinese society. Administrative Science Quarterly, 42(3), 421-444. http://dx.doi.org/10.2307/2393733

Frenkel, S., Li, M., \& Restubog, S. L. D. (2012). Management, organizational justice, and emotional exhaustion among Chinese migrant workers: Evidence from two manufacturing organizations. British Journal of Industrial Relations, 50(1), 121-147. http://dx.doi. org/10.1111/j.1467-8543.2011.00858.x

Gascón, S., Leiter, M. P., Stright, N., Santed, M. A., Montero-Marín, J., Andrés, E., ... \& García-Campayo, J. (2013). A factor confirmation and convergent validity of the "Areas of Worklife Scale" (AWS) to Spanish translation. Health and Quality of Life Outcomes, 11(63), 1-11. http://dx.doi.org/10.1186/1477-7525-11-63

Green, D. E., Walkey, F. H., \& Taylor, A. J. (1991). The three-factor structure of the Maslach Burnout Inventory: A multicultural, multinational confirmatory study. Journal of Social Behavior \& Personality, 6(3), 453-472.

Hopkins, S. M., \& Weathington, B. L. (2006). The relationships between justice perceptions, trust, and employee attitudes in a downsized organization. The Journal of Psychology, 140(5), 477-498. http://dx.doi.org/10.3200/JRLP.140.5.477-498

Hubbell, A. P., \& Chory-Assad, R. M. (2005). Motivating factors: Perceptions of justice and their relationship with managerial and organizational trust. Communication Studies, 56(1), 47-70. http://dx.doi.org/10.1080/0008957042000332241

Hughes, L. W., Avey, J. B., \& Norman, S. M. (2008). A study of supportive climate, trust, engagement and organizational commitment. Journal of Business \& Leadership: Research, Practice and Teaching 4(2), 51-59. Retrieved from http://digitalcommons.cwu.edu/ cobfac $/ 260$

Karasek Jr, R. A. (1979). Job demands, job decision latitude, and mental strain: Implications for job redesign. Administrative Science Quarterly, 24(2), 285-308. http://dx.doi. org $/ 10.2307 / 2392498$

Karasek, R. T., \& Theorell, T. T. (1990). Healthy work: Stress, productivity and the reconstruction of working life. New York, NY: Basic Books.

Kickul, J., \& Lester, S. W. (2001). Broken promises: Equity sensitivity as a moderator between psychological contract breach and employee attitudes and behavior. Journal of Business and Psychology, 16, 191-217. http://dx.doi.org/10.1023/A:1011105132252

Kim, H. (2011). Job conditions, unmet expectations, and burnout in public child welfare workers: How different from other social workers? Children and Youth Services Review, 33(2), 358-367. http://dx.doi.org/10.1016/j.childyouth.2010.10.001

Kline, R. B. (2011). Principles and practice of structural equation modeling. New York, NY: Guilford Press. 
Kroon, B., van de Voorde, F. C., \& van Veldhoven, M. J. P. M. (2009). Crosslevel effects of high-performance work practices on burnout: Two counteracting mediating mechanisms compared. Personnel Review, 38(5), 509-525. http://dx.doi. org/10.1108/00483480910978027

Lackritz, J. R. (2004). Exploring burnout among university faculty: Incidence, performance, and demographic issues. Teaching and Teacher Education, 20(1), 713-729. http://dx.doi. org/10.1016/j.tate.2004.07.002

Langballe, E. M., Innstrand, S. T., Aasland, O. G., \& Falkum, E. (2011). The predictive value of individual factors, work-related factors, and work-home interaction on burnout in female and male physicians: A longitudinal study. Stress and Health, 27(1), 73-87. http:// dx.doi.org/10.1002/smi.1321

Lasalvia, A., Bonetto, C., Bertani, M., Bissoli, S., Cristofalo, D., Marrella, G., ... \& Ruggeri, M. (2009). Influence of perceived organisational factors on job burnout: Survey of community mental health staff. The British Journal of Psychiatry, 195(6), 537-544. http:// dx.doi.org/10.1192/bjp.bp.108.060871

Lau, D. C., Liu, J., \& Fu, P. P. (2007). Feeling trusted by business leaders in China: Antecedents and the mediating role of value congruence. Asia Pacific Journal of Management, 24(3), 321-340. http://dx.doi.org/10.1007/s10490-006-9026-Z

Lee, R. T., \& Ashforth, B. E. (1993). A further examination of managerial burnout: Toward an integrated model. Journal of Organizational Behavior, 14(1), 3-20. http://dx.doi. org./10.1002/job.4030140103

Leiter, M. P. (1992). Burn-out as a crisis in self-efficacy: Conceptual and practical implications. Work \& Stress, 6(2), 107-115. http://dx.doi.org/10.1080/02678379208260345

Leiter, M. P., \& Maslach, C. (1999). Six areas of worklife: A model of the organizational context of burnout. Journal of Health and Human Services Administration, 21(4), 472-489. Retrieved from http://www.jstor.org/stable/25780925

Leiter, M. P., \& Maslach, C. (2004). Areas of worklife: A structured approach to organizational predictors of job burnout. In P. Perrewé \& D. C. Ganster (Eds.), Research in occupational stress and well-being (vol. 3, pp. 91-134). Oxford, UK: Elsevier.

Leiter, M. P., \& Maslach, C. (2006). Areas of worklife survey manual. Wolfville, NS: Center for Organizational Research and Development.

Leiter, M. P., \& Shaughnessy, K. (2006). The areas of worklife model of burnout: Tests of mediation relationships. Ergonomia: An International Journal, 28, 327-341. Retrieved from http://cord.acadiau.ca/tl_files/sites/cord/resources/Documents/SixAreasOfWorklife1999. pdf

Leiter, M. P., Frank, E., \& Matheson, T. J. (2009). Demands, values, and burnout: Relevance for physicians. Canadian Family Physician, 55, 1224-1225. Retrieved from http://www. cfp.ca/content/55/12/1224.short

Li, P. P. (2008). Toward a geocentric framework of trust: An application to organizational trust. Management and Organization Review, 4(3), 413-439. http://dx.doi.org/10.1111/ j.1740-8784.2008.00120.x

MacCallum, R. C., Browne, M. W., \& Sugawara, H. M. (1996). Power analysis and determination of sample size for covariance structure modeling. Psychological Methods, 1(2), 130-149. http://dx.doi.org/10.1037/1082-989X.1.2.130 
MacKinnon, D. P., Lockwood, C. M., Hoffman, J. M., West, S. G., \& Sheets, V. (2002). A comparison of methods to test mediation and other intervening variable effects. Psychological Methods, 7(1), 83-104. http://dx.doi.org/10.1037/1082-989X.7.1.83

MacKinnon, D. P., Lockwood, C. M., \& Williams, J. (2004). Confidence limits for the indirect effect: Distribution of the product and resampling methods. Multivariate Behavioral Research, 39(1), 99-128. http://dx.doi.org/10.1207/s15327906mbr3901_4

Maslach, C. (1993). Burnout: A multidimensional perspective. In W. B. Schaufeli, C. Maslach, \& T. Marek (Eds.), Professional burnout: Recent developments in theory and research (pp. 19-32). Washington, DC: Taylor and Francis.

Maslach, C. (2003). Job burnout: New directions in research and intervention. Current Directions in Psychological Science, 12(5), 189-192. http://dx.doi.org/10.1111/14678721.01258

Maslach, C., \& Leiter, M. P. (1997). The truth about burnout. New York, NY: Jossey-Bass.

Maslach, C., \& Leiter, M. P. (2008). Early predictors of job burnout and engagement. Journal of Applied Psychology, 93(3), 498. http://dx.doi.org/10.1037/0021-9010.93.3.498

Maslach, C., Jackson, S. E., \& Leiter, M. P. (1996). MBI: The Maslach burnout inventory: Manual. Palo Alto, CA: Consulting Psychologists Press.

Maslach, C., Schaufeli, W. B., \& Leiter, M. P. (2001). Job burnout. Annual Review of Psychology, 52(1), 397-422. http://dx.doi.org/10.1146/annurev.psych.52.1.397

Maslanka, H. (1996). Burnout, social support and AIDS volunteers. AIDS Care, 8(2), 195-206.

Masterson, S. S., Lewis, K., Goldman, B. M., \& Taylor, M. S. (2000). Integrating justice and social exchange: The differing effects of fair procedures and treatment on work relationships. Academy of Management Journal, 43(4), 738-748. http://dx.doi. org/10.2307/1556364

Mayer, R. C., Davis, J. H., \& Schoorman, F. D. (1995). An integrative model of organizational trust. Academy of Management Review, 20(3), 709-734. http://dx.doi.org/10.5465/ AMR.1995.9508080335

Moorman, C., Deshpande, R., \& Zaltman, G. (1993). Factors affecting trust in market research relationships. The Journal of Marketing, 57(1), 81-101. http://dx.doi.org/10.2307/1252059

Murat, M. (2003). Üniversite öğretim elemanlarında tükenmişlik [Burnout among university academic staff]. Türk Psikolojik Danışma ve Rehberlik Dergisi, 2(19), 25-34.

Noblet, A. J., \& Rodwell, J. J. (2009). Integrating job stress and social exchange theories to predict employee strain in reformed public sector contexts. Journal of Public Administration Research and Theory, 19, 555-578. http://dx.doi.org/10.1093/jopart/mun019

Nunnally, J. C. (1978). Psychometric theory. New York, NY: McGraw Hill.

Özkanal, Ü., \& Arikan, N. (2010). Investigation of burnout among instructors working at ESOGU preparatory school. English Language Teaching, 3(1), 166-172.

Paliszkiewicz, J. O. (2011). Trust management: Literature review. Management, 6(4), 315-331.

Posner, B. Z. (1992). Person-organization values congruence: No support for individual differences as a moderating influence. Human Relations, 45(4), 351.

Preacher, K. J., \& Kelley, K. (2011). Effect size measures for mediation models: Quantitative strategies for communicating indirect effects. Psychological Methods, 16(2), 93-115. http://dx.doi.org/10.1037/a0022658 
Robinson, S. L. (1996). Trust and breach of the psychological contract. Administrative Science Quarterly, 41, 574-599. http://dx.doi.org/10.2307/2393868

Rousseau, D. M. (1989). Psychological and implicit contracts in organizations. Employee Responsibilities and Rights Journal, 2, 121-139. http://dx.doi.org/10.1007/BF01384942

Schaufeli, W. B., Leiter, M. P., Maslach, C, \& Jackson, S. E. (1996). MBI-General Survey. In C. Maslach, S. E. Jackson \& M. P. Leiter (Eds.), Maslach burnout inventory manual (pp. 19-26). Palo Alto, CA: Consulting Psychologists Press.

Shirom, A. (2003). Job-related burnout: A review. In J. C. Quick \& L. E. Tetrick (Eds.), Handbook of occupational health psychology (pp. 245-264). Washington, DC: American Psychological Association.

Schwab, R. L., \& Iwanicki, E. F. (1982). Perceived role conflict, role ambiguity, and teacher burnout. Educational Administration Quarterly, 18(1), 60-74. http://dx.doi. org/10.1177/0013161X82018001005

Shrout, P. E., \& Bolger, N. (2002). Mediation in experimental and nonexperimental studies: New procedures and recommendations. Psychological Methods, 7(4), 422-445. http:// dx.doi.org/10.1037/1082-989X.7.4.422

Siegall, M., \& McDonald, T. (2004). Person-organization value congruence, burnout and diversion of resources. Personnel Review, 33(3), 291-301. http://dx.doi.org/ $10.1108 / 00483480410528832$

Siegrist, J. (1996). Adverse health effects of high-effort/low-reward conditions. Journal of Occupational Health Psychology, 1(1), 27-41. http://dx.doi.org/10.1037/1076-8998.1.1.27

Sousa-Lima, M., Michel, J. W., \& Caetano, A. (2013). Clarifying the importance of trust in organizations as a component of effective work relationships. Journal of Applied Social Psychology, 43(2), 418-427. http://dx.doi.org/10.1111/j.1559-1816.2013.01012.x

Taşdan, M., \& Yalçın, T. (2010). İlköğretim okulu öğretmenlerinin algıladıkları sosyal destek ile örgütsel güven düzeyleri arasındaki ilişki düzeyi [Relationship between primary school teachers' perceived social support and organizational trust level, educational sciences]. Educational Sciences: Theory \& Practice, 10, 2569-2620.

Tayfur, O., \& Arslan, M. (2013). The role of lack of reciprocity, supervisory support, workload and work-family conflict on exhaustion: Evidence from physicians. Psychology, Health \& Medicine, 18(5), 564-575. http://dx.doi.org/10.1080/13548506.2012.756535

Tepper, B. J. (2001). Health consequences of organizational injustice: Tests of main and interactive effects. Organizational Behavior and Human Decision Processes, 86(2), 197-215. http://dx.doi.org/10.1006/obhd.2001.2951

Timms, C., Graham, D., \& Caltabiano, M. (2006). Gender implication of perceptions of trustworthiness of school administration and teacher burnout/job stress. Australian Journal of Social Issues, 41(2), 343-358.

Toker, B. (2011). Job satisfaction of academic staff: An empirical study on Turkey. Quality Assurance in Education, 19(2), 156-169. http://dx.doi.org/10.1108/09684881111125050

Trent, L. M. Y. (1997). Enhancement of the school climate by reducing teacher burnout: Using an invitational approach. Journal of Invitational Theory and Practice, 4(2), 103-114. Retrieved from http://eric.ed.gov/?id=EJ559288 
Truchot, D., \& Deregard, M. (2001). Perceived inequity, communal orientation and burnout: The role of helping models. Work \& Stress, 15(4), 347-356. http://dx.doi. org/10.1080/02678370110086380

Tschannen-Moran, M. (2001). Collaboration and the need for trust. Journal of Educational Administration, 39(4), 308-331. http://dx.doi.org/10.1108/EUM0000000005493

Tschannen-Moran, M., \& Hoy, A. W. (2001). Teacher efficacy: Capturing an elusive construct. Teaching and Teacher Education, 17(7), 783-805. http://dx.doi.org/10.1016/ S0742-051X(01)00036-1

Tschannen-Moran, M. (2014). The interconnectivity of trust in schools. In D. Van Maele, P. B. Forsyth, \& M. Van Houtte (Eds.), Trust and school life: The role of trust for learning, teaching, leading, and bridging (pp. 57-82). Dordrecht: Springer Science.

Tümkaya, S. (2006). Faculty burnout in relation to work environment and humor as a coping strategy. Educational Sciences: Theory \& Practice, 6, 911-921.

Van Dierendonck, D., Schaufeli, W. B., \& Sixma, H. J. (1994). Burnout among general practitioners: A perspective from equity theory. Journal of Social and Clinical Psychology, 13(1), 86-100.

Van Horn, J. E., Schaufeli, W. B., \& Enzmann, D. (1999). Teacher Burnout and lack of reciprocity. Journal of Applied Social Psychology, 29(1), 91-108. http://dx.doi. org/10.1111/j.1559-1816.1999.tb01376.x

Van Yperen, N. W., Buunk, B. P., \& Schaufeli, W. B. (1992). Communal orientation and the burnout syndrome among nurses. Journal of Applied Social Psychology, 22(3), 173-189. http://dx.doi.org/10.1111/j.1559-1816.1996.tb01853.x

Vosselman, E. G. J., \& Van der Meer-Kooistra, J. (2009). Accounting for control and trust building in interfirm transactional relationships. Accounting, Organizations and Society, 34(2), 267-283. http://dx.doi.org/10.1016/j.aos.2008.04.002

Watts, J., \& Robertson, N. (2011). Burnout in university teaching staff: A systematic literature review. Educational Research, 53(1), 33-50. http://dx.doi.org/10.1080/00131881.2011.55 2235

Webster, J. (2014). Shaping women's work: Gender, employment and information technology. London \& New York: Routledge.

Wong, C. A., \& Cummings, G. G. (2009). The influence of authentic leadership behavior on trust and work outcomes of health care staff. Journal of Leadership Studies, 3(2), 6-23. http://dx.doi.org/ http://dx.doi.org/10.1002/jls.20104 